\title{
Teknik Pengujian Kinerja Algoritme Relay Jarak Menggunakan DIgSILENT
}

\author{
(The Technique of Distance Relay Algorithm Performance Testing Using \\ DIgSILENT)
}

\author{
Nanang Rohadi ${ }^{1}$, Nendi Suhendi ${ }^{2}$, Liu Kin Men $^{3}$
}

\begin{abstract}
This paper presents a novel technique of testing to evaluate the performance of the transmission line protection relay algorithms (model SEL-421 distance relay) using DIgSILENT. The purpose of this publication is to provide an understanding of using DIgSILENT software for testing protection relays. The accuracy of the fault impedance measurement algorithm due to the influence of the system uncertainty factor can be simultaneously observed and tested automatically. The effects of the fault resistance and the power flow angle are considered as uncertainty factors. In the proposed method, the fault simulation on the transmission line is carried out at a number of different fault locations with factors are varied based on the value of the sample parameter and changed simultaneously to see the effect of relay performance. A random sample of parameters is generated over a certain range of values. Automatic testing has been applied through an algorithm developed with DIgSILENT's DPL (DIgSILENT Programming Language). The examples presented in this publication explaining the proposed methods of testing which can also be used to their practical use. In this publication, the method for testing distance relay has been successfully implemented through a combination of DIgSILENT and MATLAB.
\end{abstract}

Intisari-Makalah ini menyajikan teknik orisinal pengujian untuk mengevaluasi kinerja algoritme relay proteksi saluran transmisi (relay jarak model SEL-421) menggunakan DIgSILENT. Tujuan yang diharapkan dari publikasi ini adalah untuk memberikan pemahaman tentang penggunakan software DIgSILENT untuk pengujian relay proteksi. Akurasi dari algoritme pengukuran impedans kegagalan yang diakibatkan oleh pengaruh faktor ketidakpastian sistem dapat diamati secara bersamaan dan dilakukan pengujian secara otomatis. Misalnya, pengaruh dari resistans kegagalan dan sudut aliran daya adalah dianggap sebagai faktor ketidakpastian. Pada metode pengujian yang ditawarkan, simulasi gangguan pada saluran transmisi dilakukan pada sejumlah lokasi gangguan yang berbeda dengan perubahan nilai dari parameter ketidakpastian berdasarkan nilai sampel parameter dan diubah secara serentak untuk melihat pengaruh terhadap kinerja relay. Sampel parameter ketidakpastian yang digunakan dibangkitkan secara acak pada rentang nilai tertentu. Pengujian otomatis telah diaplikasikan melalui algoritme yang dikembangkan dengan DIgSILENT Programming Language (DPL) pada DIgSILENT. Contoh yang disajikan pada publikasi ini menjelaskan tentang metode pengujian yang ditawarkan dapat juga digunakan untuk

1,2 Jurusan Teknik Elektro, Fakultas MIPA, Universitas Padjadjaran, Kampus Jatinangor, Sumedang, Jawa Barat, 45364 (tlp: 0812-9082 0565; e-mail: nanang.rohadi@unpad.ac.id)

${ }^{3}$ Jurusan Teknik Fisika Fakultas MIPA, Universitas Padjadjaran, Kampus Jatinangor, Sumedang, Jawa Barat, 45364 mendemontrasikan kegunaannya secara praktis. Pada makalah ini, metode untuk pengujian relay jarak telah berhasil diimplementasikan melalui kombinasi software DIgSILENT dan MATLAB.

Kata Kunci-Relay Jarak, Saluran Transmisi, Pengujian Relay, Parameter Ketidakpastian.

\section{Pendahuluan}

Tujuan dari penggunaan proteksi relay jarak pada sistem tenaga listrik adalah untuk mendeteksi gangguan yang mengindikasikan terjadinya gangguan pada sistem saluran transmisi. Selanjutnya, tindakan untuk mengisolasi gangguan dilakukan agar kondisi abnormal tidak menyebar ke bagian lain dari sistem. Seiring dengan meningkatnya tingkat kompleksitas sistem tenaga, yang ditandai dengan saluran transmisi yang cukup panjang dan penyaluran daya melalui saluran transmisi yang semakin meningkat karena keterbatasan saluran, relay proteksi yang bekerja secara analog sudah tidak mampu lagi untuk memenuhi persyaratan kinerja yang baik sebagai relay proteksi saluran.

Oleh karena itu, penggunaan relay digital yang jauh lebih andal dalam mengatasi masalah dalam hal perlindungan terhadap gangguan perlu dilakukan, terutama karena kelebihan pada kecepatan dan akurasinya [1]-[4]. Dalam hal ini, saat ini masih dikembangkan cara untuk meningkatkan kinerja relay proteksi digital. Untuk mengembangkan kinerja relay, tentu diperlukan laboratorium yang digunakan untuk keperluan pengujian relay atau bisa juga digunakan dengan melakukan pemodelan dan dilakukan pengujian dengan simulasi terhadap sejumlah gangguan melalui alat bantu software aplikasi DIgSILENT PowerFactory [5]. Dalam melakukan studi terhadap kinerja algoritme relay jarak SEL-421 [6], ada dua tahap yang perlu dilakukan, yaitu: 1) menentukan data percobaan gangguan untuk sejumlah skenario gangguan; dan 2) menguji algoritme relay dengan sejumlah data gangguan melalui model sistem yang dikembangkan. Simulasi pengujian melalui kombinasi kedua tahapan tersebut dapat dilakukan secara bersamaan dengan melakukan otomasi melalui algoritme yang dikembangkan menggunakan DIgSILENT Program Language (DPL) yang difasilitasi oleh DIgSILENT. Model sistem pengujian yang dikembangkan dengan DIgSILENT memungkinkan terjadinya interaksi antara model sistem daya dengan sejumlah variasi gangguan dan model dari relay jarak SEL-421. Pada makalah ini, integrasi kerja antara model relay dan model dari sistem daya untuk pengujian dijalankan secara otomatis melalui algoritme yang 


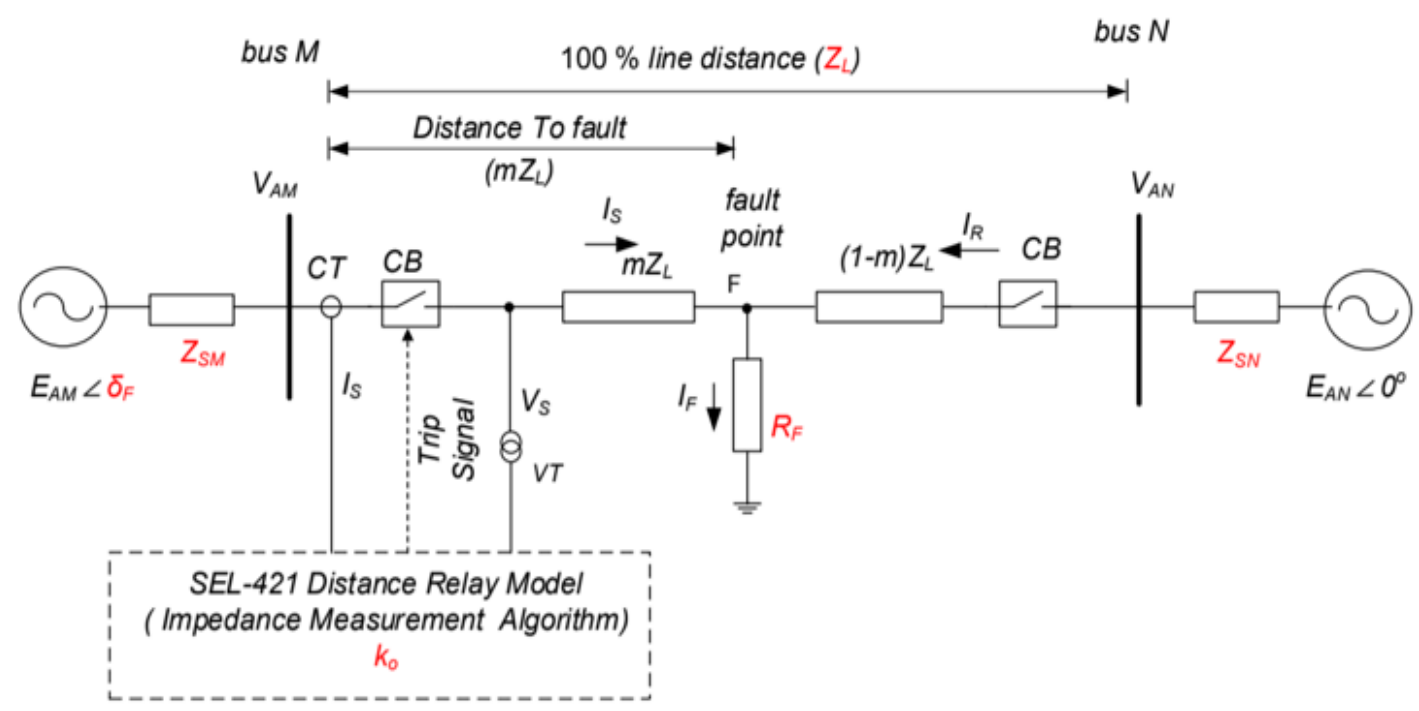

Gbr. 1 Diagram model sistem pengujian dengan nilai ketidakpastian.

dikembangkan dengan program DPL. Teknik yang dikembangkan akan sangat berguna untuk peningkatan pemahaman terhadap konsep kerja relay proteksi untuk para insinyur maupun akademisi.

\section{MODEL SISTEM}

\section{A. Format Pemodelan}

Model yang dikembangkan pada software DIgSILENT menggunakan bahasa simbol yang dapat diartikan oleh software tersebut. Model pada DIgSILENT digunakan untuk fungsi pengawasan, pengendalian, dan perhitungan yang dapat dikaitkan dengan algoritme yang dikembangkan dengan DPL [5], yang digunakan untuk otomasi pada proses simulasi. Simbol dapat bekerja secara repetitif, kondisional, dan berdasarkan fungsinya, sesuai yang telah didefinisikan oleh pengguna. Model sistem yang dikembangkan dengan DIgSILENT mempunyai fitur yang baik dan juga dapat diintegrasikan dengan MATLAB [7] melalui data yang dibangkitkan dan disimpan melalui satu variabel dan file yang telah didefinisikan sebelumnya. Gbr. 1 adalah model sistem interkoneksi rangkaian tunggal yang diimplementasi dengan software DIgSILENT untuk keperluan sejumlah simulasi dan pengujian kinerja dari relay jarak model SEL-421. Pada Gbr. 1 tersebut, gangguan fase tunggal ke tanah (ground) dengan resistans gangguan disimulasi antara dua sumber rangkaian Thevenin. Resistans gangguan $R_{F}$ disusun oleh kabel pentanahan, resistans tower, dan lain-lain. Selama gangguan fase ke tanah, karakteristik resistans akan menghasilkan drop tegangan melalui resistans gangguan $R_{F}$ yang berbanding lurus dengan arus $I_{F}$ [8]. Dalam hal ini, akurasi relay yang digunakan untuk mengukur impedans gangguan dipengaruhi oleh arus kegagalan $I_{F}$, dengan sudut aliran beban $\delta_{F}$ dapat memengaruhi perubahan nilai arus $I_{F}$.

Impedans sumber $Z_{S M}$, impedansi saluran tidak homogen $Z_{L}$, dan arus yang mengalir ke titik gangguan adalah faktor yang memengaruhi nilai $I_{F}$. Kombinasi dari resistans gangguan $R_{F}$ dan sudut aliran beban $\delta_{F}$ merupakan faktor yang sangat dominan pada akurasi kerja relay pada saat terjadi gangguan [9].

\section{B. Implementasi Relay Jarak Model SEL-421}

Relay jarak SEL-421 adalah relay jarak (digital) yang digunakan untuk melindungi saluran transmisi pada kondisi gangguan [6]. Relay ini memiliki teknologi yang sudah maju dan berbasis mikroprosesor sehingga mudah untuk dilakukan pemeliharaan dan mempunyai kinerja yang sangat baik. Relay ini dapat bekerja secara cepat dan sangat independen dalam melindungi peralatan saat kondisi gangguan. Pada kondisi gangguan, relay mendeteksi gangguan melalui sinyal transien tegangan dan arus melalui sinyal keluaran dari Current Transformer (CT) dan Voltage Transformer (VT). Selanjutnya, dari kedua sinyal tersebut nilai impedans gangguan dihitung oleh algoritme yang ada di dalamnya. Keandalan kerja dari relay jarak model SEL-421 dapat dipengaruhi oleh antialiasing low-pass filter dan dc-offset dan juga kerja Discrete Forier Transform (DFT) yang digunakan untuk menghasilkan sinyal arus dan tegangan yang siap digunakan untuk menghitung impedans gangguan secara cepat dan akurat. Kecepatan dan keakuratan dalam kerja relay proteksi saluran transmisi tegangan tinggi adalah isu yang masih terus dipelajari dan dikembangkan oleh para praktisi maupun akademisi.

Untuk mendapatkan perhitungan impedans gangguan, model sistem seperti pada Gbr. 1 harus dibuat dengan bantuan DIgSILENT. Simbol yang dinyatakan dengan warna merah adalah nilai ketidakpastian yang dapat memengaruhi akurasi kerja algoritme relay yang selanjutnya akan diamati dan disajikan dalam makalah ini. Untuk keperluan studi terhadap kinerja relay jarak (relay jarak SEL-421), struktur model yang terdiri atas model relay dan model sistem akan menyimulasi sejumlah variasi gangguan dan sekaligus menghitung nilai impedans gangguan $\underline{Z}_{m}$.

Gbr. 2 menunjukkan model SEL-421 yang disederhanakan [5], yaitu model yang diintegrasikan dalam model sistem daya pada Gbr. 1, yang mengandung sejumlah blok fungsi, di antaranya blok fungsi "polarizing" (dinyatakan dengan nomor 


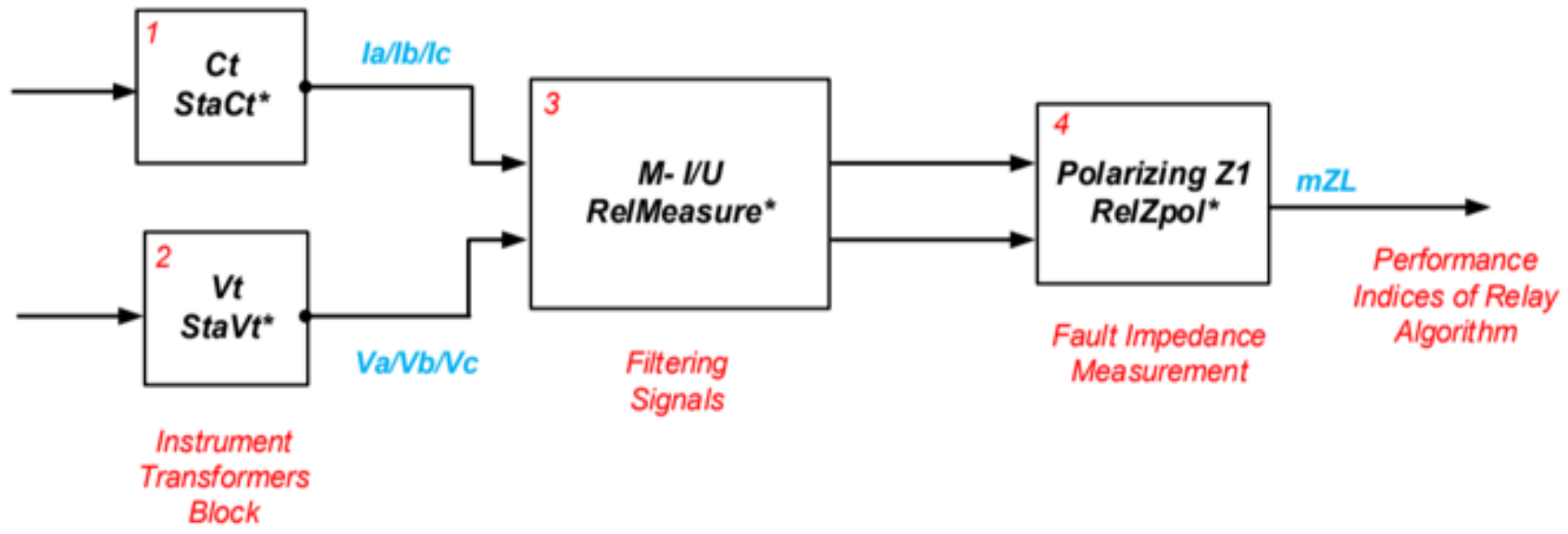

Gbr. 2 Blok sistem untuk perhitungan impedans gangguan.

4). Blok ini mengandung algoritme untuk fungsi pengukuran impedans gangguan yang akan diamati kinerjanya.

Fungsi blok CT dan VT yang dinyatakan dengan nomor 1 dan 2 dihubungkan dengan saluran yang terdapat pada model sistem daya (Gbr. 1). Kedua trafo instrumen ini berfungsi untuk mengubah nilai nyata pada sistem daya menjadi nilai sekunder yang dijadikan masukan relay proteksi (relay jarak). Selanjutnya, dilakukan proses perhitungan impedans gangguan.

Fungsi blok yang dinyatakan dengan nomor 3 adalah sebagai blok "RelMeasure". Dalam blok ini, fungsi transformasi Analog-to-Digital Converter (ADC), anti-aliasing low pass filters, digital low pass filters, Discrete Cosine Transform (DCT), dan Discrete Forier Transform (DFT) dilakukan untuk mengubah sinyal analog menjadi sinyal diskret dan selanjutnya dilakukan perhitungan untuk menentukan nilai phasor terhadap arus dan tegangan gangguan yang diperlukan oleh elemen proteksi dan fungsi pengukuran pada blok berikutnya. Blok 4 melakukan perhitungan impedans gangguan berdasarkan nilai phasor tegangan dan arus yang dihasilkan oleh fungsi DFT. Pada blok ini diperlukan pengaturan sejumlah nilai parameter, misalnya faktor koreksi urutan nol, $\underline{k}_{o}$.

\section{Otomasi Simulasi Gangguan}

Simulasi gangguan dapat dilakukan secara otomatis melalui algoritme yang dikembangkan dalam skrip program di DPL. Dalam hal ini, program DPL dapat berfungsi sebagai antarmuka yang disediakan oleh DIgSILENT untuk proses simulasi gangguan secara otomatis. DPL adalah syntax yang mirip bahasa $\mathrm{C}$ yang mendukung akses tidak terbatas ke objek PowerFactory, parameter, dan fungsinya. Cakupan fungsi DPL dapat diperluas melalui $C$-interface sehingga memungkinkan akses ke data dan aplikasi eksternal. Pada proyek ini, sejumlah nilai faktor ketidakpastian sistem, yang diindikasikan dengan simbol merah pada Gbr. 1, dapat diimplementasikan secara bersamaan melalui proses pembacaan data melalui sampel data ketidakpastian yang sudah dibangkitkan melalui software SIMLAB dan selanjutnya menjalankan simulasi gangguan dengan melakukan perubahan faktor ketidakpastian secara bersamaan melalui perintah pada algoritme yang dikembangkan menggunakan DPL sebagai berikut.
Var. \& Const. declaration

INPUT ... ... \% declare input file from sample data to the model system

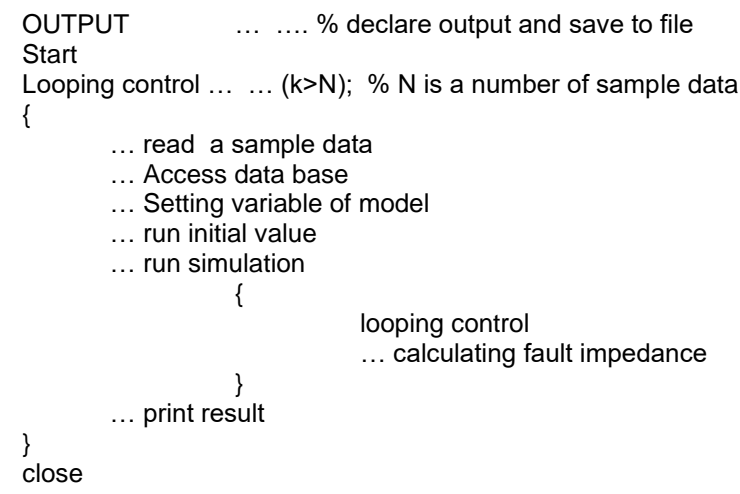

Dalam melakukan otomasi simulasi gangguan, perintah dalam DPL digunakan sebagai elemen pusat yang menghubungkan antara masukan (misalnya parameter yang telah didefinisikan sebelumnya, variabel dalam sekumpulan objek) ke sejumlah fungsi (internal elemen) dari relay dan ke keluaran (hasil) atau dalam bentuk perubahan nilai parameter.

Skrip program dengan DPL adalah contoh sebagian struktur algoritme yang dikembangkan dalam DPL untuk melakukan otomasi proses simulasi gangguan. Dalam struktur algoritme tersebut, urutan proses pekerjaan otomasi dan simulasi untuk pengujian dapat dilakukan. Perhitungan impedans gangguan dilakukan melalui proses simulasi gangguan dan dapat meliputi urutan: pembacaan data melalui sampel data dalam sebuah file, proses aktivasi fungsi-fungsi tertentu untuk melakukan perubahan parameter dalam database, fungsi perintah pengulangan sejumlah simulasi, dan perintah pengambilan hasil perhitungan impedans gangguan secara otomatis yang dilakukan pada relay jarak model SEL-421.

Dalam proses pengujian relay, skrip program pada DPL digunakan sebagai program utama untuk melakukan otomasi pengujian relay jarak SEL-421. Tingkat fleksibilitas yang tinggi dari DPL membuat algoritme yang dikembangkan tidak hanya dapat memberikan perintah memulai simulasi tetapi juga dapat digunakan untuk menghitung indeks kinerja dari algoritme relay secara bersamaan. 


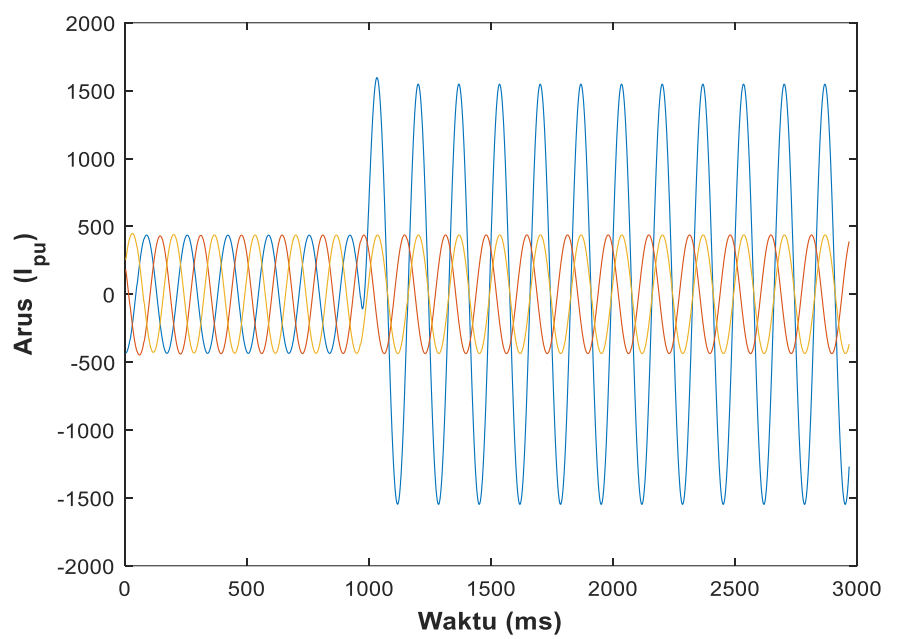

(a)

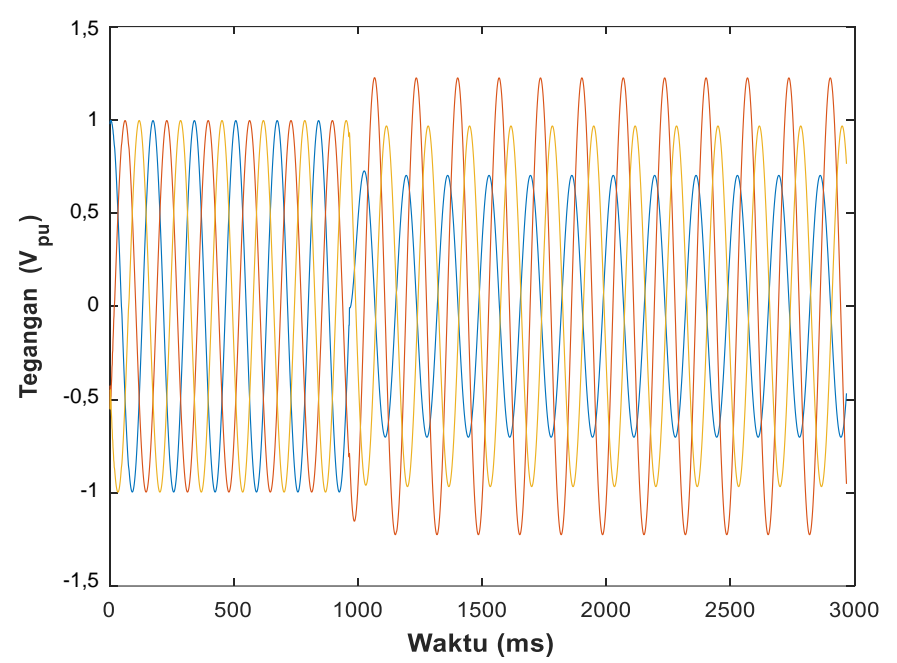

(b)

Gbr. 3 Keluaran dari CT dan VT pada kondisi gangguan, (a) arus 3-fase kondisi gangguan fase A-G, (b) tegangan 3-fase pada kondisi gangguan fase AG.

\section{EVALUASI KINERJA AlgORITME RELAY}

\section{A. Penurunan Rumus Perhitungan Impedans Gangguan}

Untuk mendemonstrasikan aplikasi dari nilai parameter ketidakpasitan sistem (seperti diindikasikan dengan warna merah pada Gbr. 1), model sistem saluran transmisi dengan gangguan telah dibuat menggunakan DIgSILENT. Sistem eksternal yang dihubungkan pada terminal $M$ dan $N$ adalah model dari rangkaian ekivalen Thevenin dengan sumber tegangan dan impedans sumber dinyatakan dengan masingmasing $\underline{E}_{A M}, \underline{E}_{A N}$ dan $\underline{Z}_{S M}, \underline{Z}_{S N}$. Gangguan disimulasikan untuk jenis kegagalan pada satu fase A ke tanah yang terjadi pada titik gangguan $F$ dan nilai resistans tanah sebesar $R_{F}$. Dalam perhitungan impedans gangguan $m \underline{Z}_{L}$, arus gangguan fase dikompensasi dengan arus urutan nol $I_{o}$ menggunakan faktor koreksi urutan nol $\underline{k}_{o}$, sedangkan $m$ adalah jarak antara lokasi relay di sisi $M$ ke titik gangguan $F$ [10]. Nilai $\underline{k}_{o}$ dipengaruhi oleh impedans urutan nol $\underline{Z}_{O L}$ yang tidak diketahui nilainya,

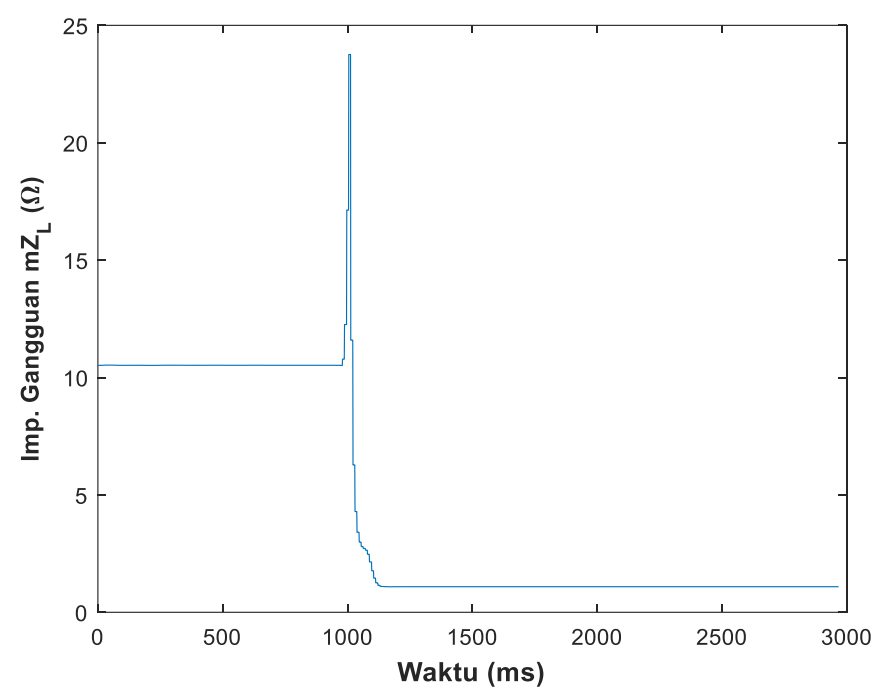

(a)

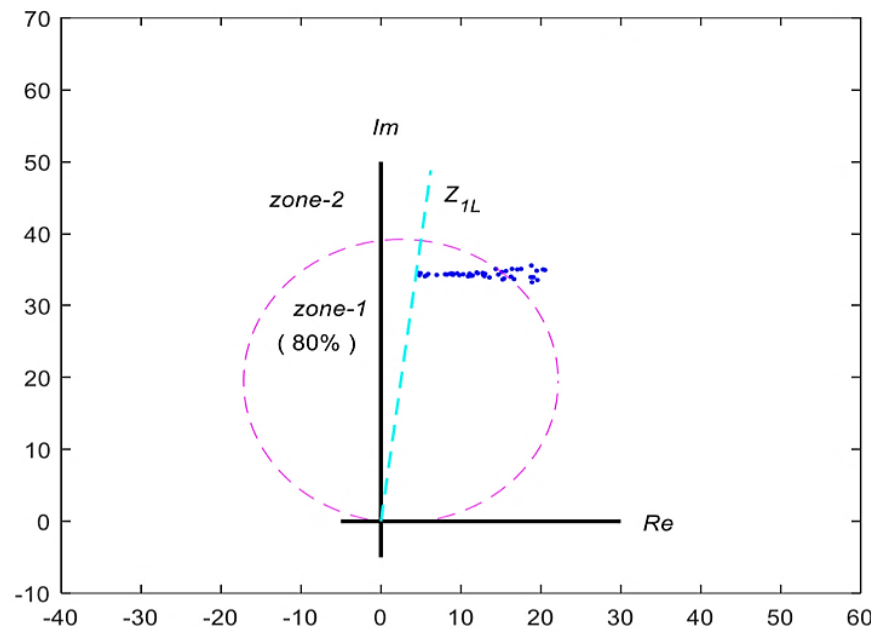

(b)

Gbr. 4 Pengukuran impedans gangguan, (a) impedans gangguan (b) pengukuran impedans dengan nilai $\left.R_{F}=0-10 \Omega, \delta_{F}:-10 ; 10 \mathrm{deg}\right)$ secara acak pada gangguan di $70 \%$.

sehingga dapat dinyatakan bahwa $\underline{k}_{o}$ dapat dianggap sebagai faktor ketidakpastian.

Untuk mengamati nilai impedans gangguan yang dihitung oleh algoritme relay terhadap gangguan di fase A ke tanah, seperti ditunjukkan pada Gbr. 1, dan selanjutnya hubungan urutan tegangan positif $\underline{V}_{1}$, tegangan negative $\underline{V}_{2}$, dan urutan tegangan nol $\underline{V}_{0}$ dan arus pada sisi $M$ untuk gangguan di titik $F$, dinyatakan dengan (1).

$$
\underline{V_{1}}+\underline{V_{2}}+\underline{V_{0}}=3 R_{F} \underline{I}_{F}
$$

Dari (1) dapat diturunkan lebih detail urutan arus dan tegangan dilihat dari posisi relay dipasang ( $\operatorname{sisi} M$ ) sebagai berikut.

$$
\begin{gathered}
\underline{V}_{1 A M}-m \underline{Z}_{1 L} \underline{I}_{1 S M}+\underline{V}_{2 A M}-m \underline{Z}_{2 L} \underline{I}_{2 S M}+\underline{V}_{0 A M} \\
-m \underline{Z}_{0 L} \underline{I}_{0 S M}=3 R_{F} \underline{I}_{F} \\
\underline{V}_{A M}=m \underline{Z}_{1 L} \underline{I}_{A M}^{c}+3 R_{F} \underline{I}_{F} .
\end{gathered}
$$




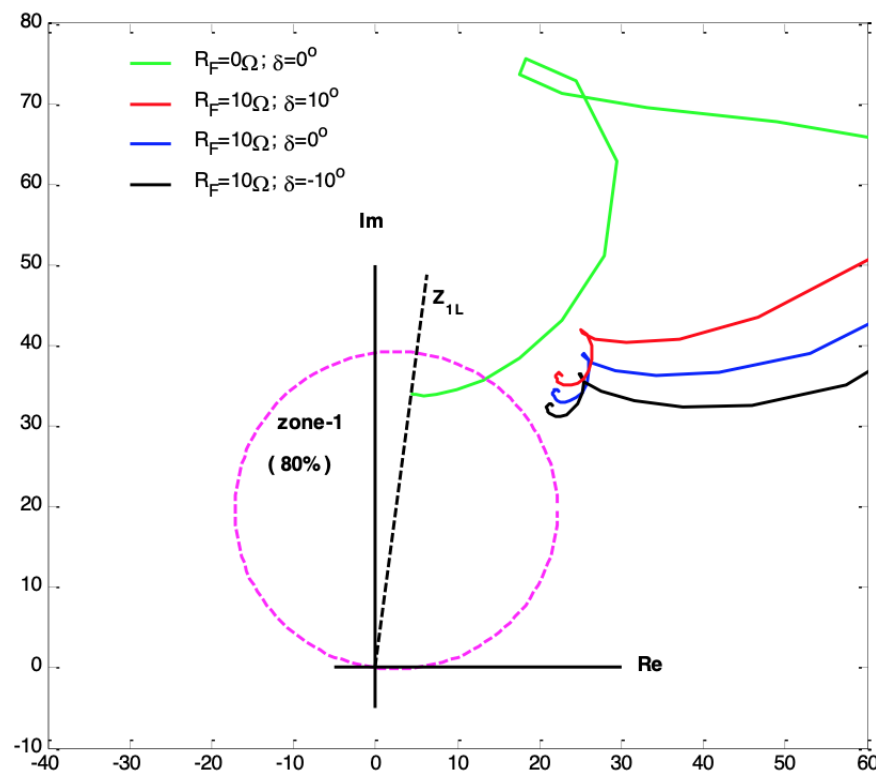

Gbr. 5 Tracking impedans gangguan untuk sejumlah skenario, $F=70 \%$.

Kompensasi arus gangguan fase A ke tanah dinyatakan dengan $\underline{I}_{A M}^{c}=\underline{I}_{A M}+k_{0} \underline{I}_{0 S M}$ dan faktor koreksi terhadap arus urutan nol adalah $\underline{k}_{0}=\left(\underline{Z}_{0 L}-\underline{Z}_{1 L}\right) / \underline{Z}_{1 L}$. Dari (1) sampai (3), selanjutnya impedans gangguan yang diestimasi oleh relay proteksi (model SEL-421) dapat dinyatakan dengan $\underline{Z}_{m}=$ $\underline{V}_{A M} / \underline{I}_{A M}^{c}$, yang dapat dipengaruhi oleh faktor ketidakpastian sistem, yaitu faktor koreksi urutan nol $\underline{k}_{0}$, resistans gangguan $R_{F}$, dan sudut aliran beban $\delta_{F}[11]$.

\section{B. Efek Faktor Ketidakpastian terhadap Kinerja Algoritme}

Untuk mengilustrasikan pengaruh faktor ketidakpastian sistem, percobaan terhadap sejumlah skenario dilakukan untuk melihat kinerja dari algoritme relay. Percobaan simulasi untuk gangguan fase A ke tanah seperti pada Gbr. 1 dilakukan untuk kondisi sistem yang sama [9] sebagai berikut: $\underline{E}_{A M}, \underline{E}_{A N}=$ $230 \angle \delta_{F} ; \quad \underline{Z}_{1 S M}, \quad \underline{Z}_{1 S N}=1,56+j 10,21 \Omega ; \quad \underline{Z}_{0 S M}, \underline{Z}_{0 S N}=$ $4,68+j 30,64 \Omega ; \operatorname{dan} \underline{Z}_{1 L}=6,25+j 48,82 \frac{\Omega}{\mathrm{km}}$.

Gbr. 3(a) dan Gbr. 4(b) masing-masing mengilustrasikan arus dan tegangan gangguan untuk kegagalan pada fase A ke tanah di titik gangguan $F=70 \%$. Pada kondisi gangguan, arus pada fase A naik secara signifikan, sementara pada tegangan terjadi sebaliknya, yaitu terjadi drop pada tegangan fase A, dibandingkan kedua fase yang tidak terganggu, yaitu fase $\mathrm{B}$ dan fase C. Gbr. 4 masing-masing menampilkan tracking hasil pengukuran impedansi pada gangguan di $70 \%$ yang dilakukan oleh algoritme relay jarak dan variasi nilai impedans pada lokasi gangguan yang sama dengan variasi nilai secara acak $R_{F}$ dan $\delta_{F}$. Karakteristik pengukuran impedans seperti Gbr. 5 adalah hasil simulasi pada gangguan di $F=70 \%$ dengan variasi pada nilai resistans $R_{F}$ dan sudut fase tegangan sumber $\delta_{F}$. Dalam simulasi terlihat bahwa pengaruh $R_{F}$ sangat dominan terhadap nilai pengukuran impedans sedangkan sudut tegangan memengaruhi nilai reaktans. Pada gangguan di $F=70 \%$, yaitu gangguan persis mendekati garis border zone-1 (80\%), yaitu

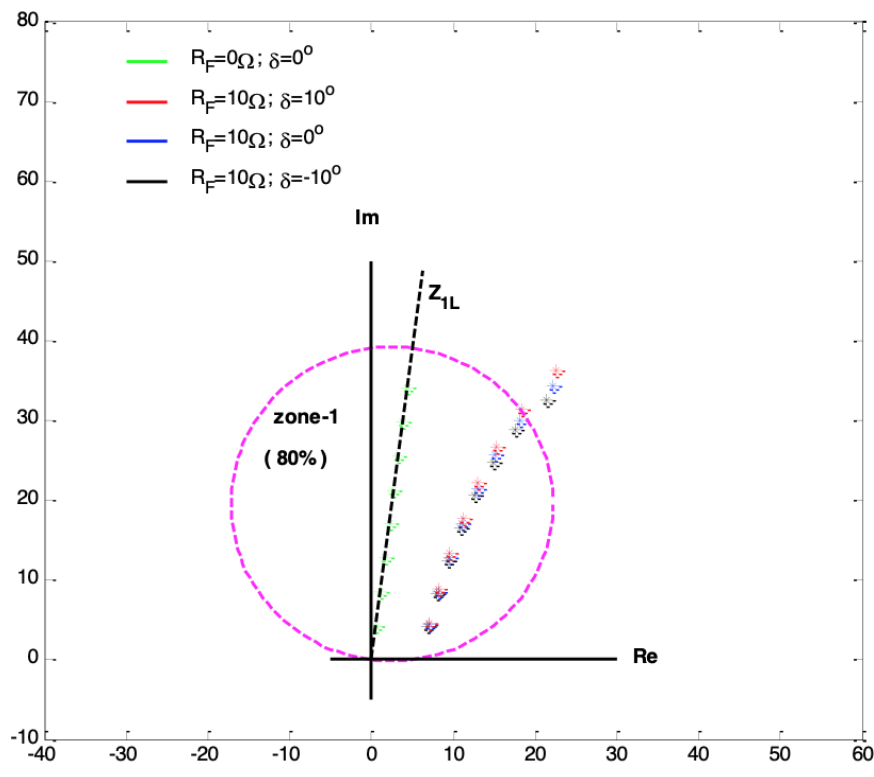

Gbr. 6 Tracking impedans untuk variasi lokasi gangguan $F=10 \%-80 \%$.

terjadi maloperasi dari relay karena relay membaca gangguan seolah terjadi di luar zone-1 (terbaca di zone-2), padahal gangguan masih di zone-1 perbatasan (80\%), sehingga proses isolasi gangguan oleh relay tertunda karena seolah gangguan terjadi di zone-2. Efek dari nilai $R_{F}$ akan memengaruhi nilai riil impedans gangguan yang mengakibatkan pengukuran impedans tergeser ke kanan, sedangkan $\delta_{F}$ akan memengaruhi nilai imajiner dari impedans. Lebih lanjut, pada Gbr. 6 diperlihatkan perubahan nilai impedans gangguan yang dihitung berdasarkan fungsi perubahan pada lokasi gangguan dari $10 \%-80 \%$. Terlihat dari hasil perhitungan impedans oleh relay bahwa pengukuran impedans cenderung menjauh dari nilai aktualnya (garis lurus diagonal) untuk gangguan yang semakin menjauh dari lokasi relay $(\operatorname{sisi} M)$.

\section{KESIMPULAN}

Makalah ini menyajikan model pembelajaran dengan menggunakan DIgSILENT untuk studi kinerja dari relay proteksi saluran transmisi (relay jarak model SEL-421). Software DIgSILENT sangat fleksibel digunakan dalam keperluan studi sistem proteksi, yaitu integrasi dengan software MATLAB dapat dilakukan dan ketersediaan DPL program dapat membantu keperluan otomasi simulasi dan analisis. Dari sejumlah percobaan dapat ditunjukkan bahwa pengaruh resistans gangguan $R_{F}$ dan sudut aliran beban $\delta_{F}$ dapat memengaruhi kinerja relay, terutama terjadinya maloperasi pada gangguan di lokasi dekat $80 \%$ (perbatasan zone-1) dari panjang saluran. Kombinasi resistans gangguan dan sudut tegangan sumber (aliran beban) juga akan menambah ketidakakuratan kerja algoritme relay, yaitu berpengaruh terhadap pembacaan nilai resistans dan reaktans untuk perhitungan impedans gangguan. Sebagai kesimpulan, metode yang telah dikembangkan dengan alat bantu DIgSILENT dapat membantu para praktisi atau siswa dalam mempelajari kerja relay. 


\section{UCAPAN TERIMA KASIH}

Ucapan terima kasih disampaikan untuk Universitas Padjadjaran dan FMIPA Unpad yang telah membantu memberikan dana dan dukungan lain pada pelaksanaan penelitian ini.

\section{REFERENSI}

[1] A.G. Padhke dan J.S. Thorp, Computer Relaying for Power Systems, Hoboken, USA: John Wiley \& Sons Inc., 1993.

[2] R.K. Aggarwal, D.V. Coury, A.T. Johns, dan A. Kalam, "A Practical Approach to Accurate Fault Location on Extra High Voltage Teed Feeders," IEEE Trans. On Power Delivery, Vol. 8, No. 3, hal. 874-883, Jul. 1993.

[3] A.A. Girgis dan C.M. Fallon, "Fault Location Techniques for Radial and Loop Transmission Systems Using Digital Fault Recorded Data," IEEE Trans. on Power Delivery, Vol. 7, No. 4, hal. 1936-1945, Okt. 1992.

[4] T.S. Sidhu, H. Singh, dan M.S. Sachdev, "Dcsign, Implementation and Testing of an Artificial Neural Network Based Fault Direction Discriminator for Protecting Transmission Lines," IEEE Trans. on Power Delivery, Vol. 10, No.2, hal. 697-706, Apr. 1995.
[5] (2008) "PowerFactory User' Manual," [Online] http://www.digsilent.de, tanggal akses: 1-Des-2020.

[6] (2007) "SEL-421 Relay Protection and Automation System User's Guide," [Online] http://www.selinc.com, tanggal akses: 17-Okt-2020.

[7] (2020) "MATLAB," [Online] http://www.mathworks.com, tanggal akses: 7-Des-2020.

[8] G.E. Alexander dan J.G. Andrichak, "Grounding Distance Relaying: Problems and Principles," Nineteenth Annual Western Protective Relaying Conference, Spokane, Washington,October, 1991.

[9] N. Rohadi dan R. Zivanovic, "Sensitivity Analysis of Impedance Measurement Algorithms Used in Distance Protection," TENCON 2011 IEEE Region 10 Conference, 2011, hal. 995-998.

[10] L. Hulka, U. Klapper, M. Putter, dan W. Wurzer, "Measurement of Line Impedance and Mutual Coupling of Parallel Lines to Improve the Protection System," 20 th International Conference on Electricity Distribution (CIRED), 2009, hal. 1-4.

[11] A.T. Funk dan O.P. Malik, "Impedance Estimation Including Ground Fault Resistance Error Correction for Distance Protection," International Journal of Electrical Power \& Energy Systems, Vol. 22, No. 1, hal. 5966,2000 